\title{
Protective immunity following vaccination with a recombinant multiple-epitope protein of bovine herpesvirus type I in a rabbit model
}

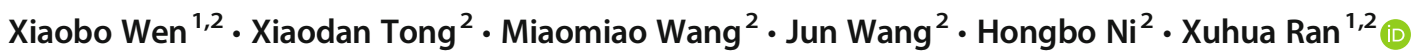

Received: 18 November 2019 / Revised: 19 January 2020 / Accepted: 26 January 2020 / Published online: 31 January 2020

(C) Springer-Verlag GmbH Germany, part of Springer Nature 2020

\begin{abstract}
Bovine herpesvirus type 1 (BoHV-1) causes considerable economic losses to the cow industry. Vaccination remains an effective strategy to control the diseases associated with BoHV-1. However, live vaccines present safety concerns, especially in pregnant cows; thus, nonreplicating vaccines have been developed to control the disease. The envelope glycoproteins of BoHV-1 induce a protective immune response. In this work, selected epitopes on glycoproteins $\mathrm{gD}, \mathrm{gC}$, and $\mathrm{gB}$ were constructed in triplicate with linker peptides. Vaccination of rabbits demonstrated that $\mathrm{P} 2-\mathrm{gD} / \mathrm{gC} / \mathrm{gB}$ with AAYAAY induced higher specific antibodies than that with GGGGS linker. P2-gD/gC/gB with AAYAAY linker was fused with bovine interleukin-6 (BoIL-6) or rabbit IL-6 (RaIL6) and bacterially expressed. Rabbits were intramuscularly immunized with $100 \mu \mathrm{g}$ of P2-gD/gC/gB-BoIL-6, P2-gD/gC/gBRaIL-6, P2-gD/gC/gB, P2-gD/gC/gB plus BoIL-6, P2-(gD-a)3-BoIL-6, or P2-(gD-a)3 emulsified with ISA 206 adjuvant thrice at 3-week intervals. $\mathrm{P} 2-\mathrm{gD} / \mathrm{gC} / \mathrm{gB}-\mathrm{BoIL}-6$ generated a higher titer of BoHV-1-specific antibodies, neutralizing antibodies, interferon (IFN)- $\gamma$, and IL-4 compared with P2-gD/gC/gB plus BoIL-6, P2-gD/gC/gB-RaIL-6, or other formulation. P2-gD/gC/gBBoIL-6 triggered similar levels of antibodies and significantly higher titer of IFN- $\gamma$ and IL- 4 compared with inactivated bovine viral diarrhea (BVD)-infectious bovine rhinotracheitis (IBR) vaccine. Rabbits vaccinated with P2-gD/gC/gB-BoIL-6 dramatically reduced viral shedding and tissue lesions in lungs and trachea after viral challenge and reactivation compared with those with P2-gD/gC/gB plus BoIL-6 or P2-gD/gC/gB-RaIL-6. P2-gD/gC/gB-BoIL-6 provided protective effects against viral shedding and tissue pathogenesis similar to those of the inactivated vaccine. The data confirmed the safety and immunogenicity of multiple-epitope recombinant protein and a potential vaccine candidate to control the disease, especially for pregnant cattle.
\end{abstract}

Keywords Bovine herpesvirus $\cdot$ Glycoprotein $\cdot$ Recombinant subunit vaccine $\cdot$ Rabbit $\cdot$ Immunogenicity

\section{Introduction}

Bovine herpes virus type 1 (BoHV-1) is an enveloped virus and a member of the genus Varicellovirus (family Herpesviridae; subfamily Alphaherpesvirinae). Systematic BoHV-1 infection may result in several diseases, including infectious bovine rhinotracheitis (IBR), infectious pustular

Xuhua Ran

ranxuhua@163.com

1 College of Animal Science and Technology, Hainan Key Lab of Tropical Animal Reproduction and Breeding and Epidemic Disease Research, Hainan University, Haidian Island, Haikou 570228, China

2 College of Animal Science \& Veterinary Medicine, Heilongjiang Bayi Agricultural University, Daqing 163319, Heilongjiang, China vulvovaginitis, balanoposthitis, conjunctivitis dependent on the viral strain, or abortion in cattle of all ages and breeds; as such, the virus presents a significant economic burden to the cattle industry not just in China but also worldwide (Jones and Chowdhury 2007; Nandi et al. 2009). Multiple infections, for example, with BoHV-1, Bovine viral diarrhea virus (BVDV), Schmallenberg virus, leptospirosis, and/or neosporosis, frequently occur in dairy cattle and cause reproductive disorders (Barrett et al. 2018; Sibhat et al. 2018). BoHV-1 infection and the resultant immunosuppressive attributes of the bovine respiratory disease complex (Ellis 2009; Jones and Chowdhury 2010) may also cause latent infection, during which, the cattle become vulnerable to subsequent infections and develop severe pneumonia or dies (Theurer et al. 2015; Whetstone and Miller 1989).

Vaccination of feedlot cattle remains an effective strategy to prevent and control the various diseases associated 
with BoHV-1 infection (Levings and Roth 2013). Numerous types of vaccines, including modified live virus (MLV) vaccine, gene-deleted live vaccine, inactivated vaccine, subunit vaccine, combined vaccine (Levings and Roth 2013; van Drunen Littel-van den Hurk et al. 1993), DNA vaccine (Quattrocchi et al. 2017), and viral vectored vaccine (Ferrer et al. 2011; Khattar et al. 2010), have been developed worldwide. Unfortunately, although MLV and gene-deleted live vaccines induce rapid immune responses, local and systematic immunity, and long-term protection, they are also abortigenic. Thus, they cannot be used to immunize pregnant cattle. Nonreplicating vaccines, such as inactivated and subunit vaccines, represent an alternative to these vaccines and may be applied to nonimmune pregnant cattle. However, cell cultures and viral purification, which would increase the cost of vaccine use, are necessary to generate inactivated vaccines. Subunit vaccines of BoHV-1 based on envelope glycoproteins are characterized by potential low cost, ease of production, and good compatibility with other vaccines for pregnant cows, especially in developing countries.

At least 12 envelope proteins of BoHV-1 have been identified (Jones and Chowdhury 2007); among which, the major envelope glycoproteins $\mathrm{gD}, \mathrm{gC}$, and $\mathrm{gB}$ simultaneously induce a protective immune response towards various diseases and are the targets of protective host immune responses (Bagley et al. 2017; Belknap et al. 1999; Caselli et al. 2005; Levings et al. 2015; Zhu and Letchworth 3rd 1996). Therefore, these glycoproteins are frequently selected by various panels for vaccine development (Levings et al. 2014), especially in subunit (Keil et al. 2005; Li et al. 1996) and DNA (Caselli et al. 2005; Mackenzie-Dyck et al. 2015) vaccines. In this study, selected epitopes on $\mathrm{gD}$ (Wang et al. 2019), $\mathrm{gC}$, and $\mathrm{gB}$ were constructed and expressed in a bacterial system to prepare an alternative subunit vaccine candidate for feedlot cattle, especially pregnant cattle. Bovine interleukin 6 (BoIL-6) or rabbit IL-6 (RaIL-6) was introduced to the recombinant protein. The immunogenicity of each recombinant multiple-epitope protein was evaluated in a rabbit model (Rock and Reed 1982).

\section{Materials and methods}

\section{Virus strain, inactivated vaccine, and animals}

BoHV-1 (Bartha Nu/67) was purchased from the China Institute of Veterinary Drug Control (Beijing, China) and propagated in Madin-Darby bovine kidney (MDBK) cells (\#HYC3044, OBio Technology Co., Ltd., Shanghai, China) cultured in minimum essential medium (MEM) supplemented with 5\% fetal bovine serum (FBS, Gibco-BRL, Grand Island, $\mathrm{NY}$, USA), $100 \mathrm{U} / \mathrm{ml}$ penicillin, and $100 \mu \mathrm{g} / \mathrm{ml}$ streptomycin at $37{ }^{\circ} \mathrm{C}$ in a $5 \% \mathrm{CO}_{2}$ humidified atmosphere (Ran et al. 2017). The viral culture was harvested and subjected to a freezing-thawing cycle when a cytopathic effect (CPE) of approximately $80 \%$ was observed, and then centrifuged at $10,000 \mathrm{r} / \mathrm{min}$ at $4{ }^{\circ} \mathrm{C}$ for $20 \mathrm{~min}$. BoHV-1 was purified by ultracentrifugation at $40,000 \times g$ at $4{ }^{\circ} \mathrm{C}$ for $2 \mathrm{~h}$ (Bechman Coulter, IN, USA). The viral pellet was resuspended in $0.01 \mathrm{M}$ phosphate buffer saline (PBS; pH 7.0), and its concentration was determined by using a Micro $\mathrm{BCA}^{\mathrm{TM}}$ Protein Assay Kit (Thermo Fisher Scientific, Shanghai, China).

Combined inactivated BVD-IBR vaccine was acquired from Spirit Jinyu Biological Pharmaceutical Co., Ltd. (Inner Mongolia Autonomous Region, China), and Chinese White rabbits were purchased from Harbin Medical University (Daqing, Heilongjiang Province). All animal experiments were carried out in accordance with the regulations of the administration of affairs concerning experimental animals and approved by the State Science and Technology Commission of the People's Republic of China.

\section{Design, expression, and purification of recombinant multiple-epitope protein}

The universal CD4+ T cell epitope of tetanus toxin P2 was introduced to the recombinant protein to enhance the immunogenicity of the resulting recombinant multiple-epitope protein (Wen et al. 2014). Table 1 lists the amino acid sequences of $\mathrm{P} 2$ and selected multiple epitopes on $\mathrm{gB}, \mathrm{gC}$, and $\mathrm{gD}$.
Table 1 Amino acid sequence of $\mathrm{P} 2$ and selected epitopes on $\mathrm{gD}$, $\mathrm{gC}$, and $\mathrm{gB}$ proteins of $\mathrm{BHoV}-1$ used in this study

\begin{tabular}{lll}
\hline Epitope & Amino acid sequence and location & Reference \\
\hline $\mathrm{P} 2$ & ${ }^{830}$ QYIKANSKFIGITEL $^{844}$ & (Wen et al. 2014) \\
$\mathrm{gD}-\mathrm{a}$ & ${ }^{323}$ GEPKPGPSPDADRPE $^{337}$ & (Wang et al. 2019) \\
$\mathrm{gD}-\mathrm{b}$ & ${ }^{253}$ VVPPYFEESKGYEPPPAA $^{270}$ & (Zhou et al. 2015) \\
$\mathrm{gD}-\mathrm{c}$ & ${ }^{202}$ LGAARGYTFGACFPARDYEQKKVL $^{225}$ & (Abdelmagid et al. 1995) \\
$\mathrm{gC}-\mathrm{a}$ & ${ }^{109}$ AGNASRDGRPS $^{119}$ & (Chowdhury 1997) \\
$\mathrm{gC}-\mathrm{b}$ & ${ }^{47}$ SAGTTGATPPTPNSPDATPEDST & \\
$\mathrm{gB}-\mathrm{a}$ & ${ }^{320}$ HREHTSYSPERFQQIEGYYKR $^{340}$ & (Chowdhury 1997) \\
$\mathrm{gB-b}$ & ${ }^{488}$ EGLFAAAAPKPGPRRARRAAP $^{508}$ & (Gao et al. 1999) \\
\hline
\end{tabular}


Figure 1a illustrates the construction of recombinant multipleepitope protein $\mathrm{P} 2-\mathrm{gD} / \mathrm{gC} / \mathrm{gB}$ protein.

Two gene fragments encoding $\mathrm{P} 2-\mathrm{gD} / \mathrm{gC} / \mathrm{gB}$ with GGGGS or AAYAAY linker were synthesized by Beijing Genomics Incorporated (Beijing, China) to test the effect of these linkers on the immunogenicity of the recombinant proteins. The genes were cloned into the prokaryotic expression plasmid pET-28a and then transformed into DH5 $\alpha$ competent cells. Recombinant bacteria were identified by using polymerase chain reaction (PCR) amplification and gene sequencing, and positive recombinant plasmids were designated as pET28a-P2-gD/gC/gB (GGGGS) and pET-28a-P2-gD/gC/gB (AAYAAY) (GenBank accession number MN750314). Each recombinant plasmid was transformed into Escherichia coli BL21 (DE3) competent cells, and the recombinant protein was induced with $1 \mathrm{mM}$ isopropyl $\beta$-d-1-thiogalactopyranoside (IPTG) at $37^{\circ} \mathrm{C}$ for $4 \mathrm{~h}$ when the optical density (OD) 600 $(\mathrm{nm})$ was approximately 0.5 . The bacteria were harvested via centrifugation at $5000 \times \mathrm{g}$ at $4{ }^{\circ} \mathrm{C}$ for $5 \mathrm{~min}$ and then washed twice with PBS. The bacterial pellet was stored at $-80{ }^{\circ} \mathrm{C}$ until use or resuspended in denaturing binding buffer with $8 \mathrm{M}$ urine. Recombinant proteins were purified by using a $\mathrm{Ni}^{+}$-NTA purification system according to the manufacturer's instructions (ThermoFisher Scientific, USA). The purified recombinant protein was refolded through overnight dialysis against $1 \mathrm{mM}$ Tris saline buffer $(\mathrm{pH} 8.0$ containing $0.1 \%$ Triton X-100) at $4{ }^{\circ} \mathrm{C}$. The concentration of each purified protein was calculated by using a Micro BCA ${ }^{\mathrm{TM}}$ Protein Assay Kit (ThermoFisher Scientific; Shanghai, China), and the level of endotoxin in each purified protein was quantified as described previously (Wen et al. 2012).

BoIL- 6 or RaIL-6 was introduced to the selected recombinant proteins to further enhance their immunogenicity. The BoIL-6 (GenBank accession number NM_173923.2) gene was synthesized, and RaIL-6 (GenBank accession number DQ680161.1) gene was generated via extraction of RNA from rabbit spleen, reverse transcriptase reaction, and conventional PCR amplification (amplification
Fig. 1 Generation of recombinant multiple-epitope protein $\mathrm{P} 2-\mathrm{gD} /$ $\mathrm{gC} / \mathrm{gB}$ and immunogenic evaluation. Panel a Schematic diagram of the construction of recombinant multiple-epitope protein $\mathrm{P} 2$ $\mathrm{gD} / \mathrm{gC} / \mathrm{gB}(\mathrm{A})$ and $\mathrm{P} 2-\mathrm{gD} / \mathrm{gC} / \mathrm{gB}$ BoIL-6 or P2-gD/gC/gB-RaIL-6 (B). Panel b Detection of BoHV1 -specific antibodies in rabbits vaccinated with multiple-epitope recombinant protein with the GGGGS or AAYAAY linker $(n=$ 3). $* P<0.05$, $* * * P<0.001$ (twoway analysis of variance (ANOVA) with Tukey's multiplecomparisons test)

\section{a}

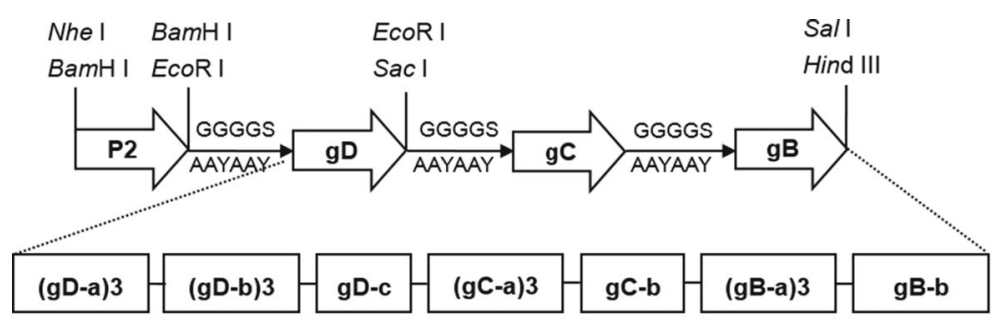

b

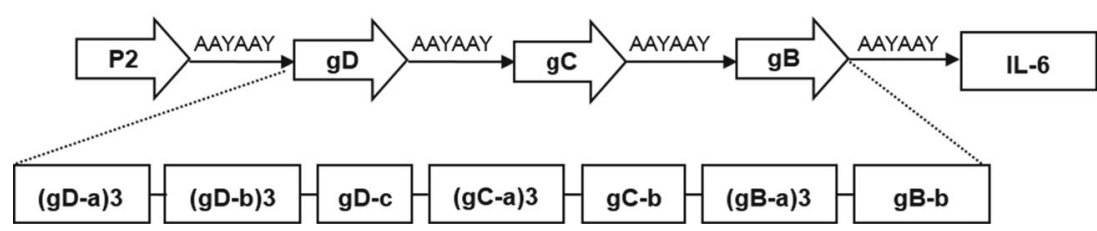

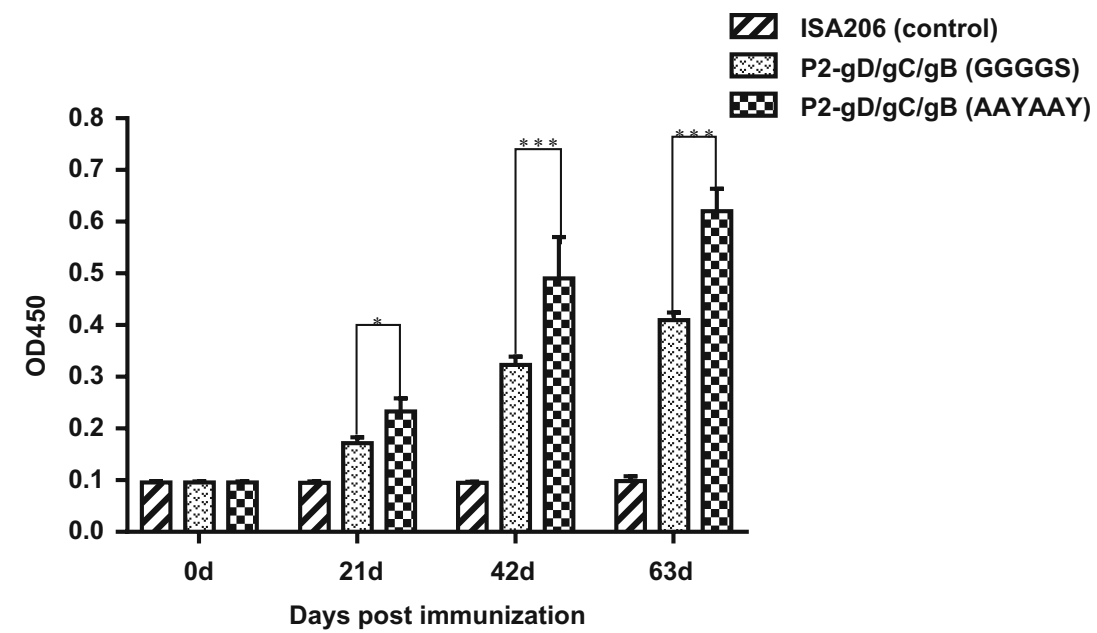


parameter not shown). Then, the gene encoding BoIL-6 or RaIL-6 was cloned into the Sal I and Hind III restriction endonuclease sites of the recombinant pET-28a-P2-gD/gC/ $\mathrm{gB}$ plasmid, resulting in the construction of recombinant plasmid pET-28a-P2-gD/gC/gB-BoIL-6 and pET-28a-P2$\mathrm{gD} / \mathrm{gC} / \mathrm{gB}-\mathrm{RaIL}-6$, respectively. pET-28a-P2-(gD-a)3BoIL-6 was constructed to generate the corresponding His-tagged recombinant proteins as the control. The recombinant protein was purified according to the process described above, and identified by using sodium dodecyl sulfate polyacrylamide gel electrophoresis (SDS-PAGE) and Western blot with a monoclonal antibody against $\mathrm{gD}$ (Wang et al. 2019) or the His-tag.

\section{Animal vaccination}

Rabbits $(n=3)$ were intramuscularly immunized thrice with $100 \mu \mathrm{g}$ of purified $\mathrm{P} 2 \mathrm{gD} / \mathrm{gC} / \mathrm{gB}$ with the GGGGS or AAYAAY linker and emulsified in an equal volume of ISA 206 adjuvant (Seppic, Paris Cedex, France) at 3-week intervals. The serum samples were harvested prior to each vaccination and 3 weeks after the final injection. The level of BoHV-1-specific antibodies was measured to evaluate the effect of either linker on immunogenicity. Then, the rabbits were randomly assigned to seven groups $(n=6)$ and intramuscularly immunized with $100 \mu \mathrm{g}$ of purified recombinant protein with the selected linker (P2-gD/gC/gB-BoIL-6, P2-gD/gC/ gB-RaIL-6, P2-(gD-a)3-BoIL-6, or P2-gD/gC/gB) and emulsified in an equal volume of ISA 206 adjuvant. Commercialinactivated BVD-IBR vaccine and ISA 206 adjuvant groups were set as the controls. The rabbits were vaccinated thrice at 3-week intervals, and the serum samples were harvested prior to vaccination and 3 weeks after the final injection. Exactly $100 \mu \mathrm{g}$ of recombinant BoIL- 6 was added to the $\mathrm{P} 2-\mathrm{gD} / \mathrm{gC} /$ $\mathrm{gB}$ protein to evaluate the immunoregulatory activity of IL-6 according to the protocol described above.

\section{Specific antibodies}

The level of BoHV-1-specific IgG was measured via an indirect enzyme-linked immunosorbent assay (ELISA), in which the ultra-centrifuged virus was used as a coating antigen. The reaction parameters were optimized on the basis of the ratio of the optical absorbance of the positive and negative sera. Briefly, 96-well plates were coated overnight with $0.2 \mu \mathrm{g}$ of virus in $100 \mu \mathrm{L}$ of $0.05 \mathrm{M}$ carbonate bicarbonate buffer $(\mathrm{pH}$ 9.6) at $4{ }^{\circ} \mathrm{C}$, followed by removal of coating buffer, and blocking with $5 \%$ nonfat milk in $0.01 \mathrm{M}$ PBS (pH 7.2, containing $0.05 \%$ Tween-20) at $37{ }^{\circ} \mathrm{C}$ for $1 \mathrm{~h}$. After washing, $100 \mu \mathrm{L}$ of 1:100-diluted rabbit serum was inoculated into each well of the ELISA plate and incubated at $37{ }^{\circ} \mathrm{C}$ for $2 \mathrm{~h}$ and then washed thrice with PBS containing $0.05 \%$ Tween- 20 . Next, $100 \mu \mathrm{L}$ of 1:5000-diluted horseradish peroxidase- conjugated goat anti-rabbit IgG (KPL, USA) was added to the wells, and the plate was incubated at $37{ }^{\circ} \mathrm{C}$ for $1 \mathrm{~h}$. Finally, the plate was developed with $100 \mu \mathrm{L}$ of TMB at $37^{\circ} \mathrm{C}$ for $15 \mathrm{~min}$, and the $\mathrm{OD}_{450} \mathrm{~nm}$ absorbance was recorded.

\section{Neutralizing antibodies}

The neutralizing activity demonstrated by various recombinant proteins in the serum was determined by using a microplate neutralization test. Each rabbit serum sample was incubated at $60{ }^{\circ} \mathrm{C}$ for $30 \mathrm{~min}$ to inactivate the complement component, serially diluted tenfold in Dulbecco's modified Eagle medium (DMEM) and incubated with $100 \times \mathrm{TCID}_{50}$ BoHV-1 at $37{ }^{\circ} \mathrm{C}$ for $1 \mathrm{~h}$ in a $5 \% \mathrm{CO}_{2}$ incubator. The mixture was inoculated onto monolayer MDBK cells in a 96-well cell culture plate, and the octa-replicates of each dilution of rabbit serum were set according to the experimental protocol. The plates were incubated at $37{ }^{\circ} \mathrm{C}$ for $120 \mathrm{~h}$ in a $5 \% \mathrm{CO}_{2}$ incubator. The CPE was recorded, and the titer of neutralizing antibodies from each group was calculated by using the modified Karber formula.

\section{Cytokine test}

Levels of IFN- $\gamma$ and IL-4 in rabbit sera were tested by using IFN- $\gamma$ or IL-4 in a commercial ELISA kit (Biocalvin; Suzhou, China). The test was conducted in triplicate according to the manufacturer's instruction.

\section{Viral challenge and reactivation}

The rabbits in all groups $(\mathrm{P} 2-\mathrm{gD} / \mathrm{gC} / \mathrm{gB}, \mathrm{P} 2-\mathrm{gD} / \mathrm{gC} / \mathrm{gB}-\mathrm{BoIL}-$ 6, P2-gD/gC/gB+BoIL-6, P2-gD/gC/gB-RaIL-6, P2-(gD-a)3BoIL-6, BVD-IBR inactivated vaccine, and ISA206 adjuvant) were intranasally challenged with $350 \mu \mathrm{L}$ of $100 \times \mathrm{TCID}_{50}$ virulent BoHV-1 3 weeks after the final vaccination, as described in Valera et al. $(2013 ; 2008)$. Nasal swabs were harvested, and the body temperature of the animals was recorded prior to the challenge and on the $1 \mathrm{st}, 3 \mathrm{rd}, 5$ th, and 7 th days post-challenge. The clinical symptoms of the rabbits were recorded, and the viral DNA in swabs was extracted by using a viral DNA preparation kit (Tiangen, Beijing, China). Viral load was quantified by using SYBR-Green fluorescence assay-based real-time qPCR with following primers: 5'GGGCATCGCCTCGTTTATT-3' and 5'-CGTG GTGATCGGGTACAGC-3' and conventional amplification parameters as described (Cardoso et al. 2013), and the results were compared with those of pMD-18- $g B$ recombinant plasmid. Three rabbits in each group were euthanized 7 days after challenge. The lung and tracheal tissues were harvested for qPCR and tissue histopathological examination. The rabbits were injected five times intramuscularly with dexamethasone $(\mathrm{DXM})$ at a dose of $0.1 \mathrm{mg} / \mathrm{kg}$ of rabbit 1 month after the 
challenge to test the reactivation of BoHV-1. Nasal swabs were harvested, and the body temperature of rabbits was recorded prior to challenge and on the $1 \mathrm{st}, 3 \mathrm{rd}, 5 \mathrm{th}$, and 7 th day post-DXM administration. The rabbits were sacrificed 7 days after DXM injection, and the lung and tracheal tissues were harvested for qPCR and tissue histopathological examination.

\section{Tissue histopathological examination}

One rabbit from each group was sacrificed 7 days postchallenge and 7 days post-DXM administration. Lung and trachea were harvested under sterile conditions to examine the protective effects of vaccination against pathological changes associated with BoHV-1 infection. The lung and tracheal tissues of rabbits were fixed with $10 \%$ formalin, conventionally dehydrated, paraffin embedded, tissue sectioned, and hematoxylin-eosin (H\&E) stained. Finally, pathological sections were observed under a microscope and recorded.

\section{Statistical analysis}

Statistical analysis by one- or two-way analysis of variance was performed by using the GraphPad Prism (Version 8.0; San Diego, CA, USA). Tukey's multiple comparison test was applied to analyze the differences between the treatment groups.

\section{Results}

\section{Selection of the linker peptide}

The expression of recombinant protein $\mathrm{P} 2-\mathrm{gD} / \mathrm{gC} / \mathrm{gB}$ protein with the GGGGS or AAYAAY linker was confirmed by using SDS-PAGE and Western blot with a monoclonal antibody against $\mathrm{gD}$ (data not shown). The titer of antibodies against BoHV-1 in the group vaccinated with $\mathrm{P} 2-\mathrm{gD} / \mathrm{gC} / \mathrm{gB}$ with the AAYAAY linker was significantly higher than that in the group vaccinated with the GGGGS linker 21 days after the first vaccination $(P<0.05), 42$ days after vaccination, and 21 days after the final vaccination $(P<0.001)$ (Fig. 1b). These results demonstrated that the linker AAYAAY enhanced the immunogenicity of the recombinant multiple-epitope protein $\mathrm{P} 2-\mathrm{gD} / \mathrm{gC} / \mathrm{gB}$. Hence, $\mathrm{P} 2-\mathrm{gD} / \mathrm{gC} / \mathrm{gB}$ with the AAYAAY linker was selected for further immunogenic analysis.

\section{Expression of recombinant protein expression}

Recombinant proteins with the AAYAAY linker were exclusively expressed in the form of inclusion bodies upon optimization of the incubation parameters and confirmed by using SDS-PAGE (Fig. 2a, b, and c). Each recombinant protein was purified by using the $\mathrm{Ni}^{+}$-NTA purification system and identified using SDS-PAGE. Western blot analysis was applied with a monoclonal antibody against the $\mathrm{gD}$ recombinant protein or His-tag was also applied (Fig. 3a, b).

\section{Serological analysis}

Levels of serum antibodies revealed that the multiple-epitope recombinant protein $\mathrm{P} 2-\mathrm{gD} / \mathrm{gC} / \mathrm{gB}-\mathrm{BoIL}-6$ induced significantly higher BoHV-1-specific antibodies than $\mathrm{P} 2-\mathrm{gD} / \mathrm{gC} /$ gB-RaIL-6 $(P<0.05)$, P2-gD/gC/gB+BoIL-6 $(P<0.001)$, or P2-(gD-a)3-BoIL-6 at 21 days after the first immunization (Fig. 4a). Furthermore, P2-gD/gC/gB-BoIL-6 triggered a significantly higher levels of antibodies than $\mathrm{P} 2-\mathrm{gD} / \mathrm{gC} / \mathrm{gB}$ RaIL-6, P2-gD/gC/gB+BoIL-6, or P2-(gD-a)3-BoIL-6 $(P<0.001)$ at 42 or 63 days after the first vaccination (Fig. $4 a)$. Notably, the inactivated BVD-IBR vaccine induced a significantly higher level of antibodies than any of the recombinant proteins 21,42 , and 63 days after the first vaccination $(P<0.001)$. However, the level of neutralizing antibodies showed no statistical significance in the groups vaccinated with the inactivated vaccine or P2-gD/gC/gB-BoIL-6 (Fig. 4b) 42 and 63 days after vaccination, respectively. P2-gD/ gC/gB-BoIL-6 induced significantly higher neutralizing antibodies than P2-gD/gC/gB-RaIL-6, P2-gD/gC/gB+BoIL-6, $\mathrm{P} 2-\mathrm{gD} / \mathrm{gC} / \mathrm{gB}$, or P2-(gD-a)3-BoIL-6 at 42 or 63 days $(P<0.05$ or $<0.01)$ after vaccination. Moreover, the titer of neutralizing antibodies in the $\mathrm{P} 2-\mathrm{gD} / \mathrm{gC} / \mathrm{gB}$ group was higher than that in the P2-(gD-a)3-BoIL-6 group at 42 and 63 days after vaccination.

\section{Cytokine test}

The recombinant protein $\mathrm{P} 2-\mathrm{gD} / \mathrm{gC} / \mathrm{gB}-\mathrm{BoIL}-6$ induced significantly higher levels of IFN- $\gamma$ than P2-gD-6 $(P<0.001)$ 21 days after vaccination (Fig. 4c). Notably, the titer of IFN- $\gamma$ induced by P2-gD/gC/gB-BoIL- 6 was higher than that elicited by the inactivated vaccine $(P>0.05)$. However, at 42 and 63 days, the IFN- $\gamma$ titer significantly increased $(P<0.001)$. P2-gD/gC/gB-BoIL-6 elicited a significantly higher level of IFN- $\gamma$ than P2-gD-6 $(P<0.001)$ and triggered higher titers of IFN- $\gamma$ than P2-gD/gC/gB-RaIL-6, P2-gD/gC/ $\mathrm{gB}+\mathrm{BoIL}-6$, or $\mathrm{P} 2-\mathrm{gD} / \mathrm{gC} / \mathrm{gB}$ after vaccination $(P>0.05$; Fig. $4 \mathrm{c}$ ). By contrast, $\mathrm{P} 2-\mathrm{gD} / \mathrm{gC} / \mathrm{gB}-\mathrm{BoIL}-6$ induced significantly higher levels of IL-4 than P2-gD/gC/gB+BoIL-6 $(P<0.05)$, P2-gD/gC/gB, or P2-gD-6 $(P<0.001) 21$ days after the first dose. Furthermore, P2-gD/gC/gB-BoIL-6 elicited higher levels of IL-4 than the inactivated vaccine or $\mathrm{P} 2-\mathrm{gD} / \mathrm{gC} / \mathrm{gB}$ RaIL-6 $(P>0.05) 21$ or 42 days after the first immunization but induced significantly higher titers of IL-4 63 days after vaccination $(P<0.001 ; P<0.05)$ (Fig. 4c). 
Fig. 2 SDS-PAGE of

recombinant multiple-epitope

protein $\mathrm{P} 2-\mathrm{gD} / \mathrm{gC} / \mathrm{gB}$ with IL-6.

Panel a SDS-PAGE of P2-gD/gC/

gB-RaIL-6 chemic multiple-

epitope recombinant protein.

Panel $\mathbf{b}$ SDS-PAGE of $\mathrm{P} 2-\mathrm{gD} / \mathrm{gC} /$

gB-BoIL-6 and P2-(gD-a)3-

BoIL-6 recombinant proteins.

Panel c SDS-PAGE of BoIL-6

recombinant protein. Arrow indi-

cates recombinant protein
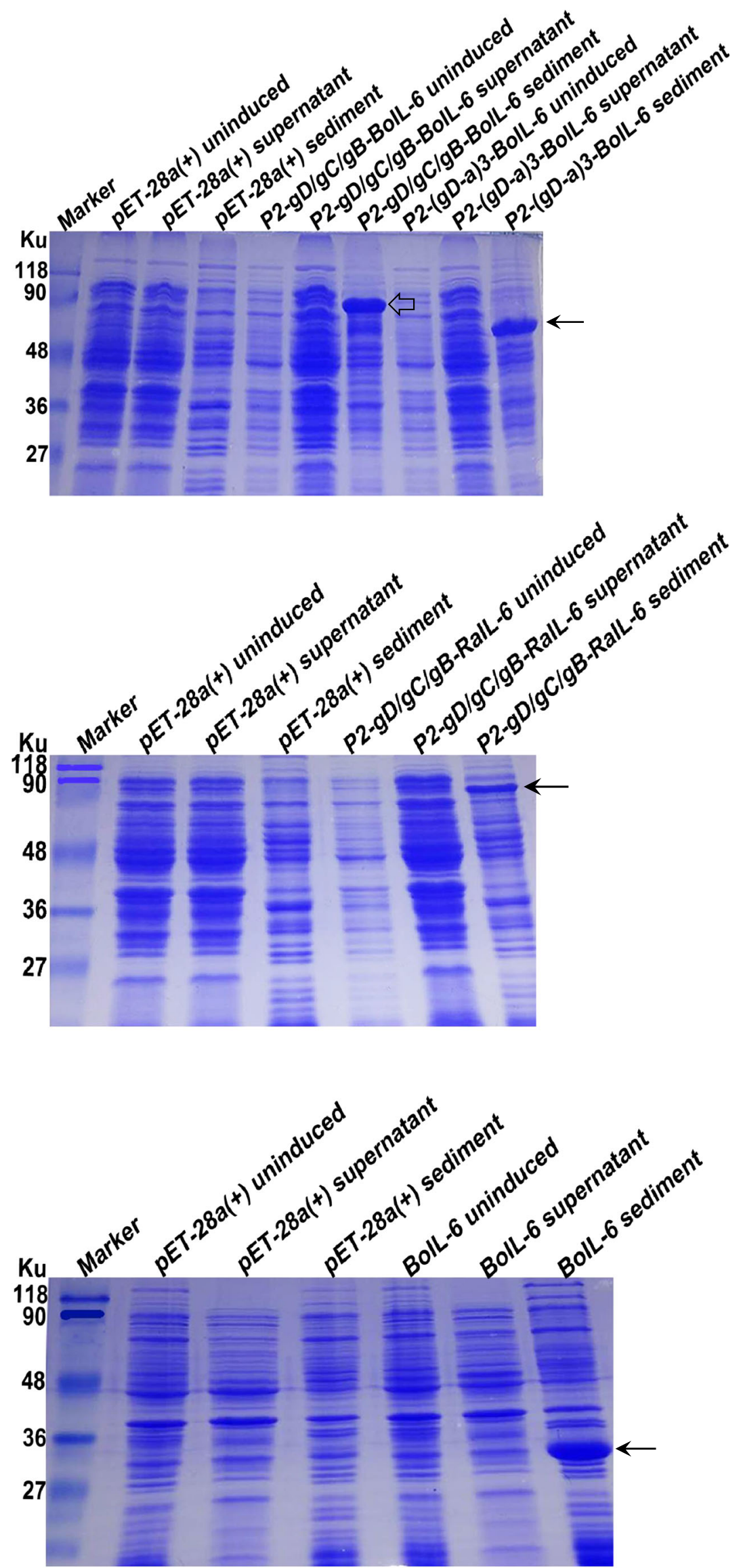


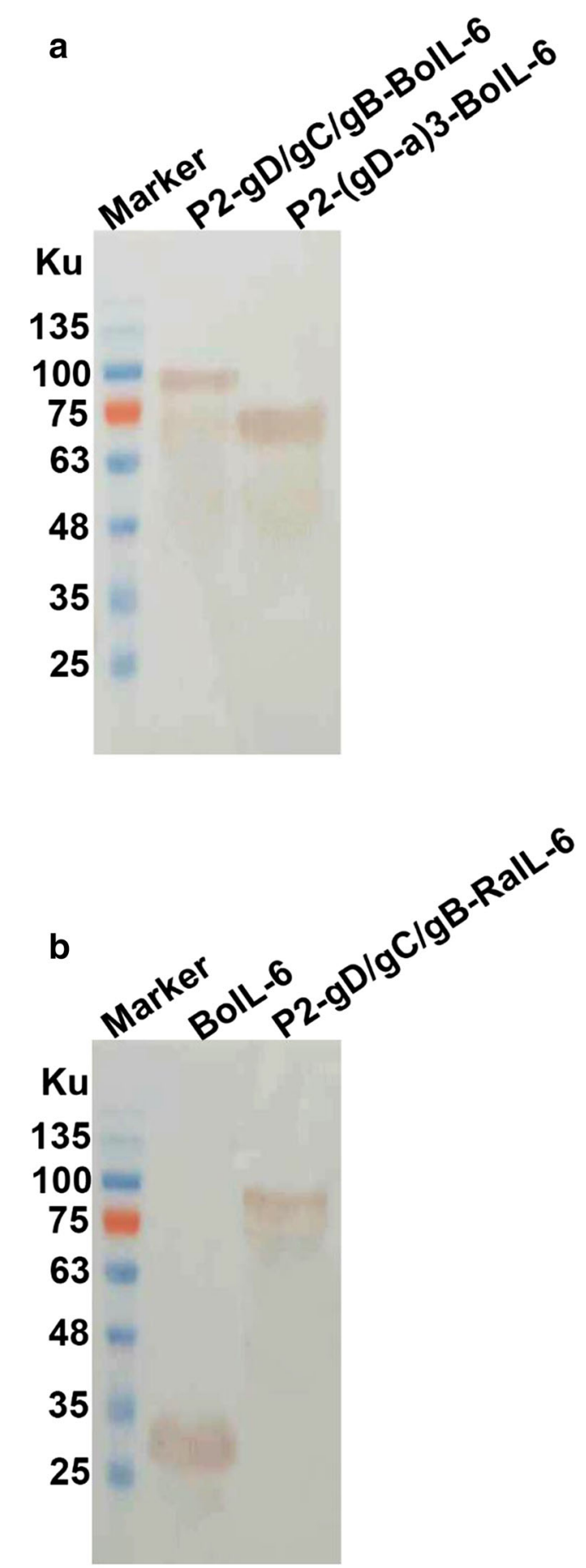

Fig. 3 Western blots analysis of recombinant proteins. Panel a Western blot analysis of P2-gD/gC/gB-BoIL-6 and P2-(gD-a)3-BoIL-6 recombinant proteins. Panel b Western blot analysis of $\mathrm{P} 2-\mathrm{gD} / \mathrm{gC} / \mathrm{gB}-$ BoIL-6 and P2-gD/gC/gB-RaIL-6 recombinant proteins

\section{Viral challenge}

Rabbits in all groups were intranasally challenged with virulent BoHV-1 3 weeks after the final immunization. Rabbits in the adjuvant control group showed nasal discharge, evident respiratory clinical signs, and relatively higher body temperature than those in other groups (Fig. 5a). Viral loads in nasal swabs were significantly lower in rabbits injected with $\mathrm{P} 2-\mathrm{gD} / \mathrm{gC} / \mathrm{gB}-\mathrm{BoIL}-6$, inactivated vaccine, or $\mathrm{P} 2-\mathrm{gD} / \mathrm{gC} / \mathrm{gB}-$ RaIL-6 than in those vaccinated with $\mathrm{P} 2-\mathrm{gD} / \mathrm{gC} / \mathrm{gB}+\mathrm{BoIL}-6$, $\mathrm{P} 2-\mathrm{gD} / \mathrm{gC} / \mathrm{gB}$, or P2-(gD-a)3-BoIL-6 1 day post-challenge (Fig. 5b). Viral load in the swabs of all groups was higher at 3 days post-challenge compared with that on day 1 but decreased after 5 days. Viral loads in the swabs of the $\mathrm{P} 2-\mathrm{gD} / \mathrm{gC} /$ gB-BoIL-6 and inactivated vaccine groups were significantly lower than in the swabs of those of other groups 3 or 5 days post-challenge (Fig. 5b). Moreover, viral loads observed in the lung tissue of rabbits after sacrifice were consistent with those in the nasal swabs (Fig. 5c).

\section{Reactivation of BoHV-1 post-challenge with DXM}

Rabbits in all groups were injected with DXM 30 days after viral challenge to evaluate whether the recombinant proteins could provide protection against the latent infection induced by BoHV-1. Rabbits in the adjuvant group presented significantly higher body temperature than those in the other groups 3 days after injection with DXM (Fig. 6a); however, the temperatures decreased on the 5th day. Viral loads in the nasal swabs or lung tissue of rabbits vaccinated with $\mathrm{P} 2-\mathrm{gD} / \mathrm{gC} / \mathrm{gB}-\mathrm{BoIL}-6$ and inactivated vaccine were significantly lower compared with those vaccinated with $\mathrm{P} 2-\mathrm{gD} / \mathrm{gC} / \mathrm{gB}+\mathrm{BoIL}-6, \mathrm{P} 2-\mathrm{gD} / \mathrm{gC} / \mathrm{gB}$, or P2-(gD-a)3BoIL-6 (Fig. 6b, c). The results demonstrate that $\mathrm{P} 2-\mathrm{gD} /$ gC/gB-BoIL-6 and inactivated vaccine provide better protection against latent infection than other recombinant proteins. Moreover, viral loads in the nasal swabs and lung tissue of rabbits vaccinated with $\mathrm{P} 2-\mathrm{gD} / \mathrm{gC} / \mathrm{gB}-\mathrm{BoIL}-6$ and inactivated vaccine were significantly low compared with those of rabbits given other vaccination. However, viral DNA was detectable after viral reactivation.

\section{Tissue histopathological examination}

Pathological section showed a slight inflammation in the lung tissue of the P2-gD/gC/gB-BoIL-6 group (Fig. 7a) but no pathological changes in the trachea (Fig. 7b). Evident tissue inflammation was absent in the lungs and trachea of the BVDIBR group after viral challenge. Lymphatic hyperplasia was observed in the lungs of the BVD-IBR vaccine group (Fig. 7c), but no changes occurred in the trachea (Fig. 7d) after reactivation by DXM. Slight inflammation was observed in the lungs of rabbits in the $\mathrm{P} 2-\mathrm{gD} / \mathrm{gC} / \mathrm{gB}-\mathrm{BoIL}-6$ group after reactivation by DXM. These findings are similar to those observed after the viral challenge. No evident damage was observed in the trachea after the administration of DXM upon vaccination with $\mathrm{P} 2-\mathrm{gD} / \mathrm{gC} / \mathrm{gB}-\mathrm{BoIL}-6$ (Fig. 7e). 


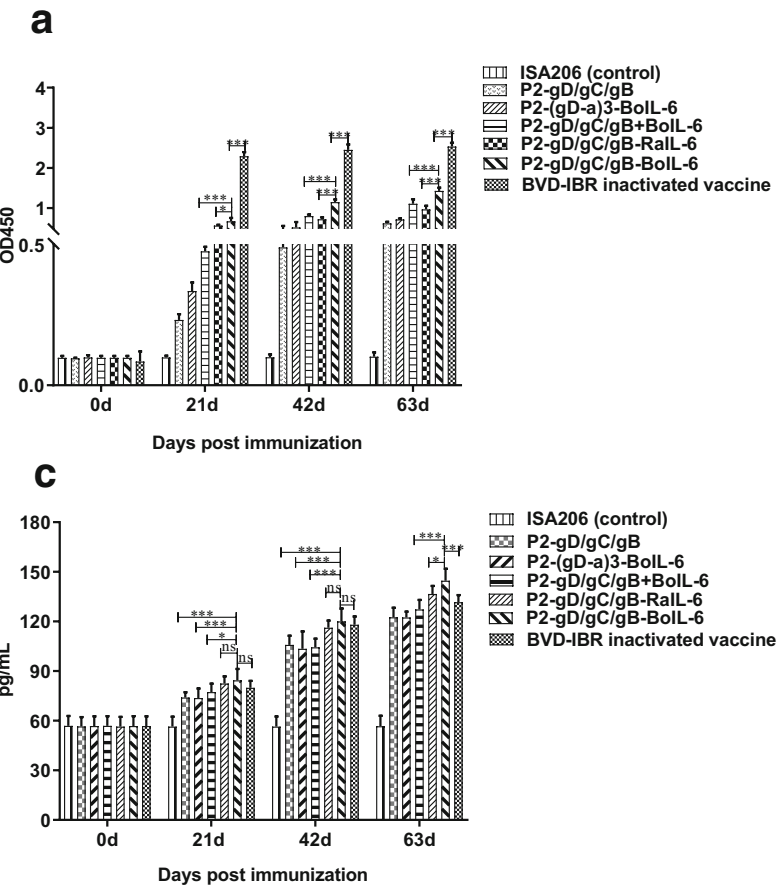

Fig. 4 Serum experiment for analysis of antibodies triggered by recombinant proteins. Panel a Level of BoHV-1-specific antibodies in rabbits vaccinated with multiple-epitope recombinant proteins with the AAYAAY linker $(n=3)$. Panel b Level of neutralizing antibodies in

\section{Discussion}

Except better immunogenicity of the multiple-epitope recombinant protein $\mathrm{P} 2-\mathrm{gD} / \mathrm{gC} / \mathrm{gB}-\mathrm{BoIL}-6$ generated in this study, the subunit vaccine candidates prepared from the $E$. coli expression system cost less and require a shorter time than other vaccine systems. However, the development of live attenuated and inactivated vaccines depends on bovine or equine serum used for cell culture, which could result in high cost or potential contamination with infectious pathogens, particularly in live attenuated vaccines. Compared with the production of live attenuated and inactivated vaccines, the generation of subunit vaccines does not require cell culture, and it is also free of safety concerns, cost-saving, and easily achievable in any laboratory with basic equipment for bacterial culture. Moreover, the proposed vaccine features ease of preparation and high yields because only multiple epitopes of $\mathrm{gB}, \mathrm{gC}$, and $\mathrm{gD}$ glycoproteins, rather than full-length proteins, are expressed in E. coli, which contributes to the ease of preparation and high yield for further production, and generation of combination vaccines with other inactivated vaccines for easy administration in clinic use.

In general, a subunit vaccine represents weaker immunogenicity, compared with conventional live attenuated and inactivated vaccines. To improve the immunogenicity of a BoHV-1 subunit vaccine candidate, in this study, a panel of multiple-epitope recombinant proteins fused with the

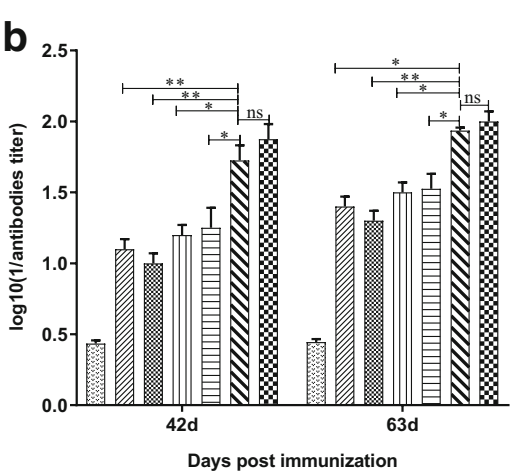

ISA206 (control) $\mathrm{P} 2-\mathrm{gD} / \mathrm{gC} / \mathrm{gB}$ P2-(gD-a)3-BolL-6 III) P2-gD/gC/gB+BolL-6 P2-gD/gC/gB-RalL-6 NV P2-gD/gC/gB-BolL-6 $\$$ BVD-IBR inactivated vaccine

d

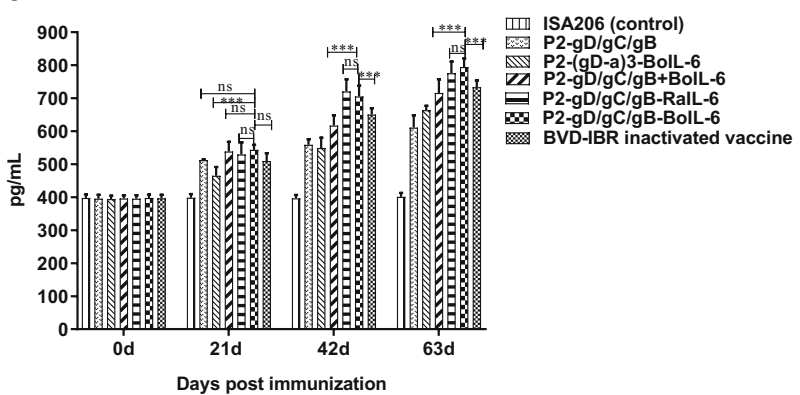

rabbits vaccinated with multiple-epitope recombinant proteins $(n=3)$. Panel $\mathbf{c}$ Level of IL-4 in the serum. Panel d Level of IFN- $\gamma$ in serum. $* P<0.05, * * P<0.01, * * * P<0.001$ (two-way analysis of variance (ANOVA) with Tukey's multiple-comparisons test)

universal $\mathrm{CD}^{+} \mathrm{T}$ cell epitope $\mathrm{P} 2$ of tetanus toxin (Kaumaya et al. 1993; Wen et al. 2014), and BoIL-6 or RaIL-6 was prepared to evaluate the immunogenicity and the potential of a vaccine candidate for pregnant cows against diseases associated with BoHV-1. The data demonstrated that the recombinant proteins could be well tolerated and are highly immunogenic. Furthermore, $\mathrm{P} 2-\mathrm{gD} / \mathrm{gC} / \mathrm{gB}-\mathrm{BoIL}-6$ induced levels of BoHV-1-specific and neutralizing antibodies and inhibited latent infection of BoHV-1 similar to the commercial BVD-IBR inactivated vaccine. Moreover, recombinant protein $\mathrm{P} 2-\mathrm{gD} /$ $\mathrm{gC} / \mathrm{gB}-\mathrm{B}$ IL- 6 triggered higher titers of IFN- $\gamma$ and IL-4 than the inactivated BVD-IBR vaccine (Fig. $4 \mathrm{c}$, d, respectively). These results suggest that the multiple-epitope recombinant proteins perform better than the inactivated vaccine in inducing cellular and humoral immune response, demonstrating potential of a vaccine candidate.

Notably, the recombinant multiple-epitope proteins in this study were constructed by introducing either a flexible GGGGS linker or a rigid AAYAAY linker between two epitopes. Although the expression parameters were optimized in this study, the recombinant proteins were exclusively expressed in the inclusion bodies. The soluble protein was assumed to induce a significantly stronger immune response than the inclusion bodies or refolded products. Therefore, other expression systems or vectors could be used for the preparation of soluble recombinant proteins that can elicit strong immune responses. In addition, vaccination with the 
a

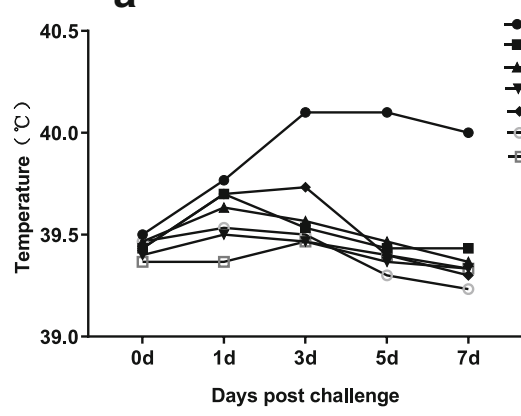

b

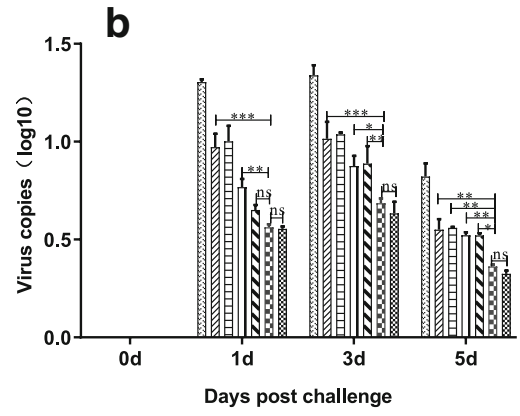

C

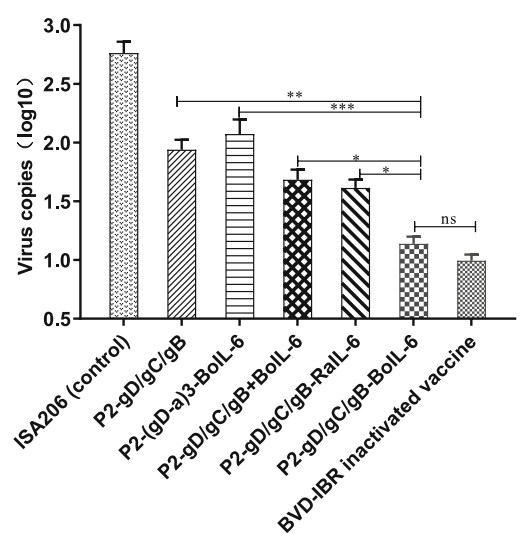

Fig. 5 Viral challenge post immunization in rabbits. Panel a Body temperature of rabbits in various groups post-challenge. Panel b Viral loads in nasal swabs of rabbits post-challenge (two-way analysis of variance (ANOVA) Tukey's multiple-comparisons test). Panel c Viral loads in the lungs of rabbits post-viral challenge (one-way analysis of variance (ANOVA) with Tukey's multiple-comparisons test). $* P<0.05$, $* * P<0.01, * * * P<0.001 ;$ ns, not significant

recombinant protein $\mathrm{P} 2-\mathrm{gD} / \mathrm{gC} / \mathrm{gB}$ with the AAYAAY linker triggered significantly higher levels of BoHV-1-specific antibodies compared with vaccination with the same protein with the GGGGS linker (Fig. 1c). Thus, epitopes in recombinant protein with the rigid linker generated in this study were assumed to be presented better and processed by antigenpresenting cells.

Various molecular adjuvants, including interleukin panels (Guo et al. 2017; Theisen-Popp et al. 1992), have been extensively explored to enhance the immunogenicity of recombinant subunit vaccines. In this study, IL-6 molecular adjuvant a
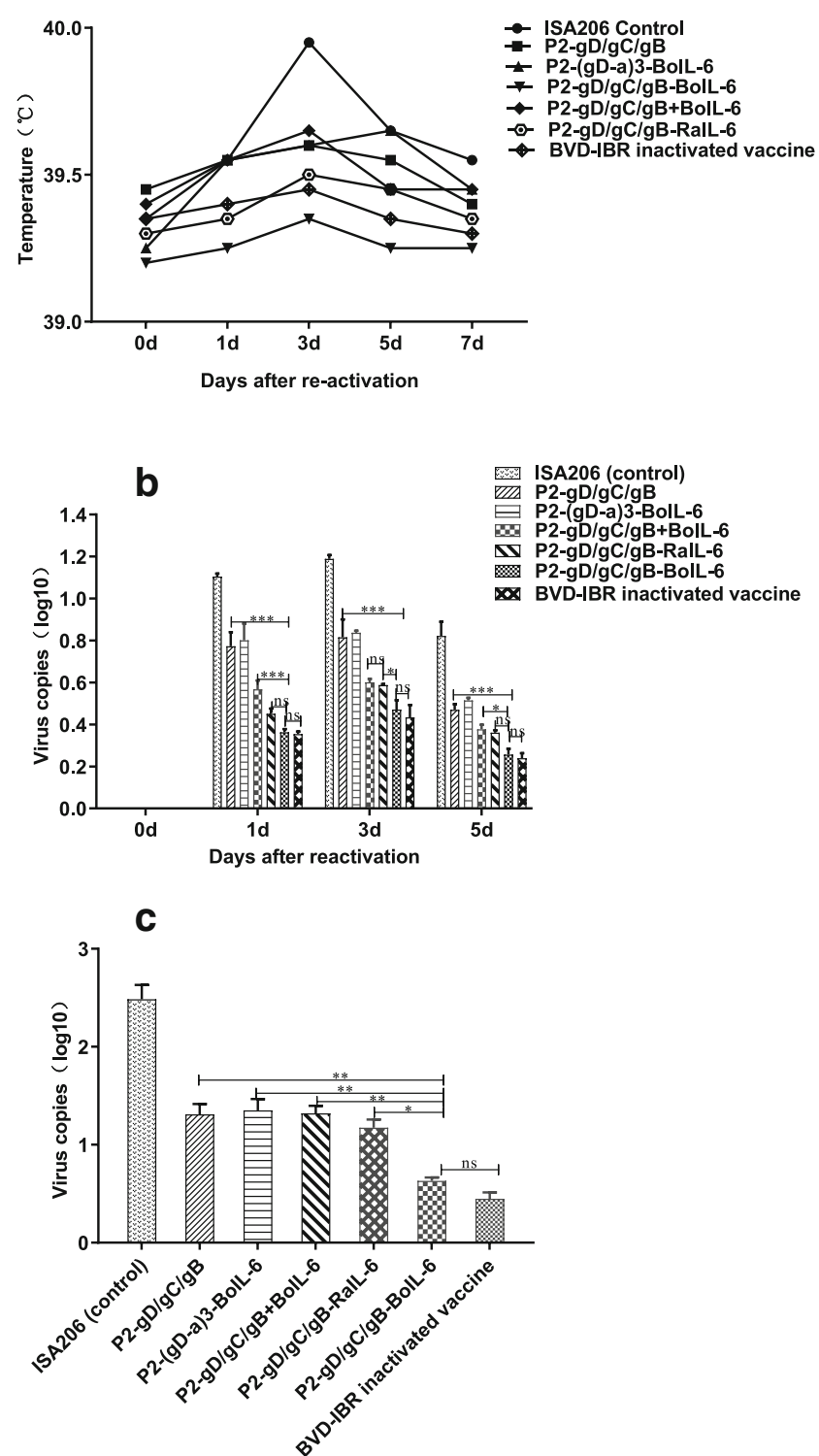

Fig. 6 Viral loads and histopathological examination of rabbits post-viral reactivation. Panel a Body temperature of rabbits in various groups postreactivation. Panel b Viral loads in the nasal swab of rabbits postreactivation (two-way analysis of variance (ANOVA) with Tukey's multiple-comparisons test). Panel c Viral loads in the lungs of rabbits post-reactivation (one-way analysis of variance (ANOVA) Tukey's multiple-comparisons test). $* P<0.05$, $* * P<0.01, * * * P<0.001$; ns, not significant

was introduced to the generated recombinant proteins. The data demonstrated that the addition of BoIL- 6 rather than RaIL-6 significantly enhances levels of BoHV-1-specific and neutralizing antibodies (Fig. 4a, b). Furthermore, recombinant protein $\mathrm{P} 2-\mathrm{gD} / \mathrm{gC} / \mathrm{gB}-\mathrm{BoIL}-6$ also induced significantly higher titers of IFN- $\gamma$ and IL- 4 compared with $\mathrm{P} 2-\mathrm{gD} / \mathrm{gC} / \mathrm{gB}$ and $\mathrm{P} 2-\mathrm{gD} / \mathrm{gC} / \mathrm{gB}$ plus BoIL- 6 at 42 and 63 days after the first immunization (Fig. 4c, d). However, the inclusion of BoIL-6 in $\mathrm{P} 2-\mathrm{gD} / \mathrm{gC} / \mathrm{gB}$ caused no significant enhancement in level of 


\section{a}
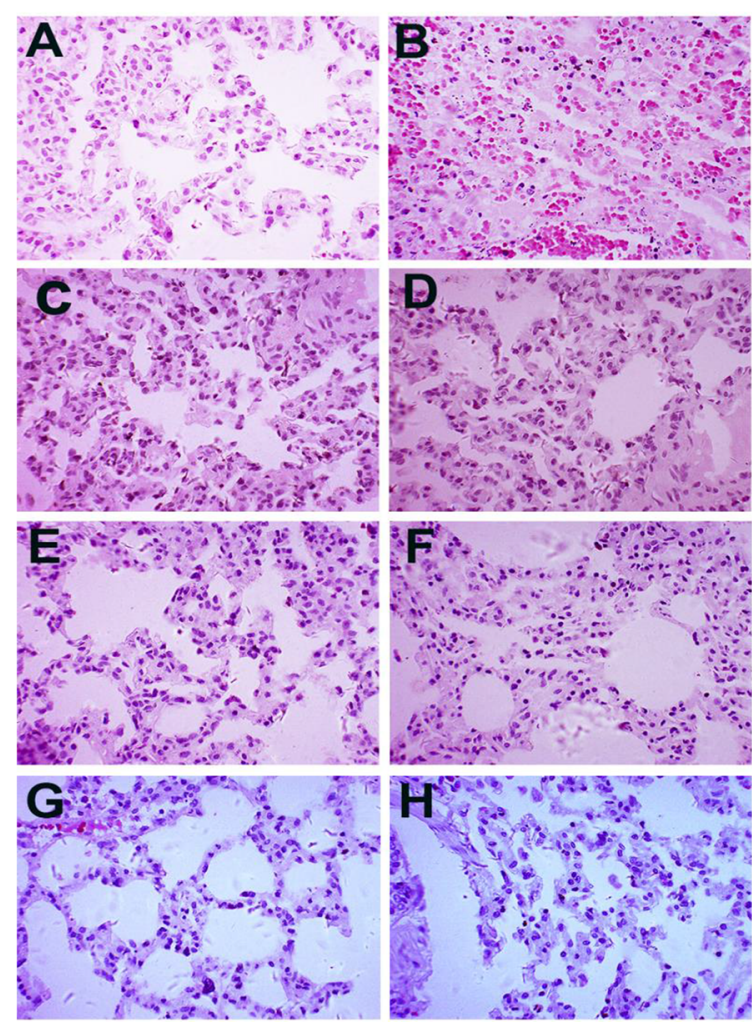

c

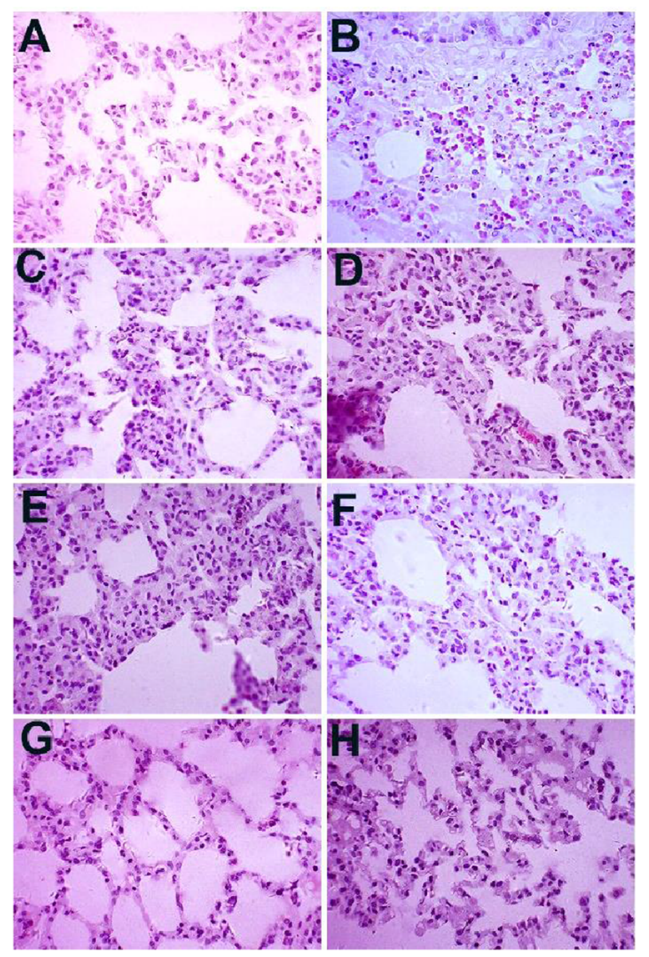

Fig. 7 Histopathological examination of rabbits post-challenge and reactivation. Histochemistry of lungs (Panel a) and trachea (Panel b) of rabbits post-challenge $(\mathrm{H} \& \mathrm{E}$ staining, $\times 400)$. A Placebo control; B ISA206 control; C P2-gD/gC/gB; D P2-(gD-a)3-BoIL-6; E P2-gD/gC/gB+BoIL6; F P2-gD/gC/gB-RaIL-6; G P2-gD/gC/gB-BoIL-6; H inactivated BVD- b

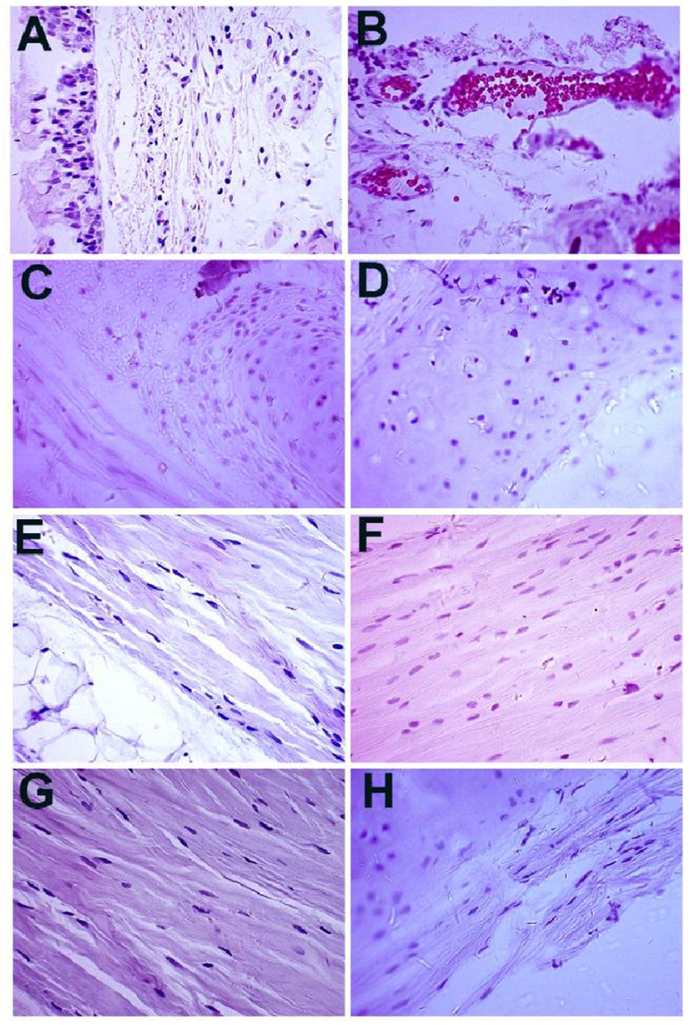

d A

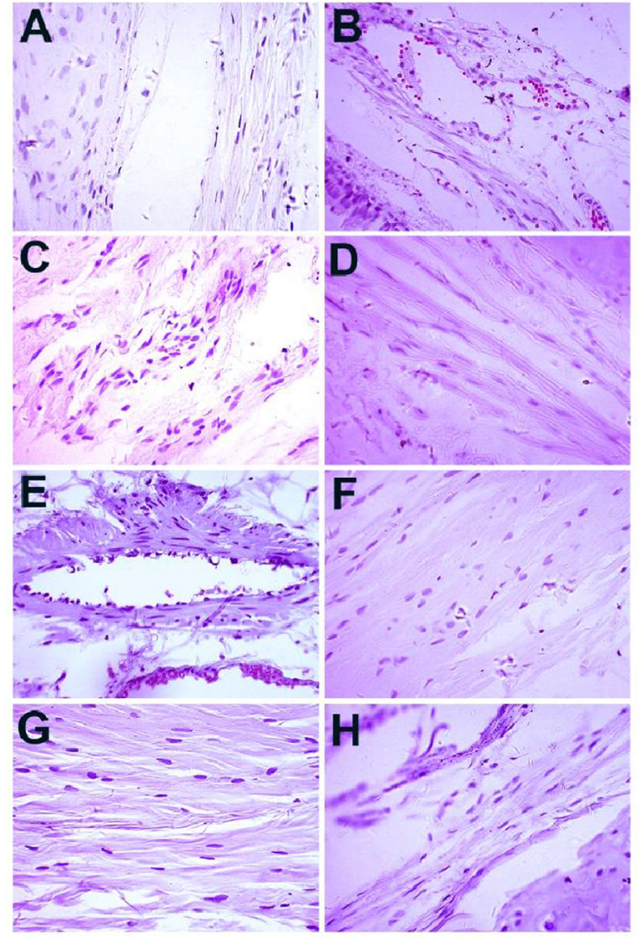

IBR vaccine. Histochemistry of lungs (Panel c) and trachea (Panel d) of rabbits post-reactivation ( $\mathrm{H} \& \mathrm{E}$ staining). A Prior to viral re-activation; $\mathrm{B}$ ISA206 control; C P2-gD/gC/gB; D P2-(gD-a)3-BoIL-6; E P2-gD/gC/ gB+BoIL-6; F P2-gD/gC/gB-RaIL-6; G P2-gD/gC/gB-BoIL-6; H inactivated $\mathrm{BVD}-\mathrm{IBR}$ vaccine 
immune response compared with the exclusive $\mathrm{P} 2-\mathrm{gD} / \mathrm{gC} / \mathrm{gB}$ recombinant protein. These results indicate that the fusion expression of BoIL- 6 with P2-gD/gC/gB may exhibit a desirable molecular adjuvant activity. Interestingly, RaIL-6 presented relatively weaker adjuvant activity than BoIL-6 in the rabbits. This phenomenon will be explored further in future studies.

BoHV-1 infection can establish persistent or latent infections in natural host species or laboratory models, including rabbits (Rock and Reed 1982). A rabbit inoculated with BoHV-1 showed respiratory clinical signs at 1-6 days after infection (Valera et al. 2008). In addition, rabbit models are appropriate for evaluating vaccine immunogenicity, viral pathogenesis, or latent infection (Liu et al. 2008; Ruiz-Saenz et al. 2013; Silva et al. 2010). Considering these characteristics, in this study, a rabbit model was also selected to assess the immunogenicity of the recombinant multiple-epitope subunit vaccine and its protective effect against viral challenge. The data demonstrated that recombinant protein $\mathrm{P} 2-\mathrm{gD} / \mathrm{gC} / \mathrm{gB}$ BoIL-6 significantly reduces the viral shedding in nasal swabs (Fig. 5b) and viral loads in the lungs (Fig. 5c) post-challenge and induces high levels of IFN- $\gamma$ and IL-4 antibodies. Furthermore, compared with other recombinant proteins, vaccination with the recombinant protein $\mathrm{P} 2-\mathrm{gD} / \mathrm{gC} / \mathrm{gB}-\mathrm{BoIL}-6$ significantly decreased viral shedding in nasal swabs and viral load in the lungs of rabbits after treatment with DXM (Fig. $6 \mathrm{~b}, \mathrm{c})$. Rabbits vaccinated with $\mathrm{P} 2-\mathrm{gD} / \mathrm{gC} / \mathrm{gB}-\mathrm{BoIL}-6$ presented a slight inflammation of the lung and tracheal tissues after viral challenge (Fig. 7a, b) and reactivation induced by DXM (Fig. 7c, d). In addition, recombinant protein P2-gD/gC/gBBoIL-6 exhibited protective effects similar to those of commercial-inactivated BVD-IBR vaccine against viral shedding, viral loads in lungs or trachea post-challenge, and reactivation of. The data demonstrate that the recombinant protein generated in this study shows high immunogenicity and protection against viral challenge.

The multiple-epitope recombinant protein $\mathrm{P} 2-\mathrm{gD} / \mathrm{gC} / \mathrm{gB}$ BoIL-6 contained the selected antigenic epitopes on glycoproteins $\mathrm{gD}, \mathrm{gC}$, and $\mathrm{gB}$, especially the conserved epitope on $\mathrm{gD}$, indicating the high identity of amino acids among the various strains of BoHV-1 species and BoHV-5 (Wang et al. 2019). The recombinant protein may likely be used to vaccinate cattle to fight against infections associated with BoHV-5. Moreover, the multiple-epitope recombinant protein was free of other BoHV-1 glycoproteins, such as $\mathrm{gE}$ and $\mathrm{gG}$; thus, it could be considered a marker vaccine or used to differentiate infected from vaccinated animals. Vaccination of cowherds with the recombinant protein combined with $\mathrm{gE}$ or $\mathrm{gG}$ antibodies in the ELISA kit can contribute to the prevention and control of diseases associated with BoHV-1 infection in cattle herds (Colitti et al. 2018; Sauerbrei and Wutzler 2004), especially in countries and regions where such infection remains a serious threat to the cow industry.
In conclusion, this study demonstrated the safety of a multiple-epitope recombinant protein in a rabbit model. The recombinant protein represented high immunogenicity, demonstrating a potential of BoHV-1 vaccine candidate. Meanwhile, the efficacy of the recombinant protein in cowherds will be evaluated in the future to develop a subunit vaccine candidate for enhanced veterinary services.

Acknowledgments The authors thank Prof. Chunling Fan for her kind assistance during preparations for the tissue pathological test and $\mathrm{H} \& \mathrm{E}$ staining.

Author contributions XW and XR designed the experiment; XT conducted protein expression, purification, and rabbit vaccination; MW and XT performed serological analysis; JW and HN conducted viral quantification and neutralizing test; XR performed statistical analysis; and XW and XR prepared the manuscript. All authors reviewed the manuscript and approved its final manuscript.

Funding information This study was funded by the project "Special Funds for the Guidance of the Central Government on Local Science and Technology Development (No. ZY18C07-16)" and the Applied Technology Research and Development Project in Heilongjiang Province (No. GC13B402).

\section{Compliance with ethical standards}

Conflict of interest The authors declare that they have no conflict of interest.

Ethical approval All applicable international, national, and/or institutional guidelines for the care and use of animals were followed.

\section{References}

Abdelmagid OY, Minocha HC, Collins JK, Chowdhury SI (1995) Fine mapping of bovine herpesvirus-1 (BHV-1) glycoprotein D (gD) neutralizing epitopes by type-specific monoclonal antibodies and sequence comparison with BHV-5 gD. Virology 206(1):242-253

Bagley KC, Schwartz JA, Andersen H, Eldridge JH, Xu R, Ota-Setlik A, Geltz JJ, Halford WP, Fouts TR (2017) An interleukin 12 adjuvanted herpes simplex virus 2 DNA vaccine is more protective than a glycoprotein D subunit vaccine in a high-dose murine challenge model. Viral Immunol 30(3):178-195. https://doi.org/10.1089/vim.2016. 0136

Barrett D, Parr M, Fagan J, Johnson A, Tratalos J, Lively F, Diskin M, Kenny D (2018) Prevalence of bovine viral diarrhoea virus (BVDV), bovine herpes virus 1 (BHV 1), leptospirosis and neosporosis, and associated risk factors in 161 Irish beef herds. BMC Vet Res 14(1):8. https://doi.org/10.1186/s12917-017-1324-9

Belknap EB, Walters LM, Kelling C, Ayers VK, Norris J, McMillen J, Hayhow C, Cochran M, Reddy DN, Wright J, Collins JK (1999) Immunogenicity and protective efficacy of a $\mathrm{gE}, \mathrm{gG}$ and US2 genedeleted bovine herpesvirus-1 (BHV-1) vaccine. Vaccine 17(18): 2297-2305

Cardoso TC, Silva-Frade C, Taparo CV, Okamura LH, Flores EF (2013) Validation of a reference control for an SYBR-green fluorescence assay-based real-time PCR for detection of bovine herpesvirus 5 in experimentally exposed bovine embryos. Mol Cell Probes 27(5-6): 237-242. https://doi.org/10.1016/j.mcp.2013.06.002 
Caselli E, Boni M, Di Luca D, Salvatori D, Vita A, Cassai E (2005) A combined bovine herpesvirus $1 \mathrm{gB}-\mathrm{gD}$ DNA vaccine induces immune response in mice. Comp Immunol Microbiol Infect Dis 28(2): 155-166. https://doi.org/10.1016/j.cimid.2004.10.001

Chowdhury SI (1997) Fine mapping of bovine herpesvirus 1 (BHV-1) glycoprotein $\mathrm{C}$ neutralizing epitopes by type-specific monoclonal antibodies and synthetic peptides. Vet Microbiol 58(2-4):309-314

Colitti B, Muratore E, Careddu ME, Bertolotti L, Iotti B, Giacobini M, Profiti M, Nogarol C, Bottcher J, Ponzo A, Facelli R, Rosati S (2018) Field application of an indirect gE ELISA on pooled milk samples for the control of IBR in free and marker vaccinated dairy herds. BMC Vet Res 14(1):387. https://doi.org/10.1186/s12917018-1716-5

van Drunen Littel-van den Hurk S, Tikoo SK, Liang X, Babiuk LA (1993) Bovine herpesvirus-1 vaccines. Immunol Cell Biol 71(Pt 5):405-420. https://doi.org/10.1038/icb.1993.47

Ellis JA (2009) Update on viral pathogenesis in BRD. Anim Health Res Rev 10(2):149-153. https://doi.org/10.1017/s146625230999020x

Ferrer MF, Del Medico Zajac MP, Zanetti FA, Valera AR, Zabal O, Calamante G (2011) Recombinant MVA expressing secreted glycoprotein D of BoHV-1 induces systemic and mucosal immunity in animal models. Viral Immunol 24(4):331-339. https://doi.org/10. 1089/vim.2011.0018

Gao Y, Wang C, Splitter GA (1999) Mapping T and B lymphocyte epitopes of bovine herpesvirus-1 glycoprotein B. J Gen Virol 80(Pt 10): 2699-2704

Guo M, Tang X, Sheng X, Xing J, Zhan W (2017) The immune adjuvant effects of flounder (Paralichthys olivaceus) interleukin-6 on E. tarda subunit vaccine OmpV. Int J Mol Sci 18(7). https://doi.org/10.3390/ ijms 18071445

Jones C, Chowdhury S (2007) A review of the biology of bovine herpesvirus type 1 (BHV-1), its role as a cofactor in the bovine respiratory disease complex and development of improved vaccines. Anim Health Res Rev 8(2):187-205. https://doi.org/10.1017/ S146625230700134X

Jones C, Chowdhury S (2010) Bovine herpesvirus type 1 (BHV-1) is an important cofactor in the bovine respiratory disease complex. Vet Clin North Am Food Anim Pract 26(2):303-321. https://doi.org/10. 1016/j.cvfa.2010.04.007

Kaumaya PT, Kobs-Conrad S, Seo YH, Lee H, VanBuskirk AM, Feng N, Sheridan JF, Stevens V (1993) Peptide vaccines incorporating a 'promiscuous' T-cell epitope bypass certain haplotype restricted immune responses and provide broad spectrum immunogenicity. $\mathrm{J} \mathrm{Mol}$ Recognit 6(2):81-94. https://doi.org/10.1002/jmr.300060206

Keil GM, Hohle C, Giesow K, Konig P (2005) Engineering glycoprotein $\mathrm{B}$ of bovine herpesvirus 1 to function as transporter for secreted proteins: a new protein expression approach. J Virol 79(2):791799. https://doi.org/10.1128/JVI.79.2.791-799.2005

Khattar SK, Collins PL, Samal SK (2010) Immunization of cattle with recombinant Newcastle disease virus expressing bovine herpesvirus-1 (BHV-1) glycoprotein D induces mucosal and serum antibody responses and provides partial protection against BHV-1. Vaccine 28(18):3159-3170. https://doi.org/10.1016/j.vaccine.2010. 02.051

Levings RL, Roth JA (2013) Immunity to bovine herpesvirus 1: II. Adaptive immunity and vaccinology. Anim Health Res Rev 14(1): 103-123. https://doi.org/10.1017/s1466252313000054

Levings RL, Stoll IR, Warg JV, Patterson PA, Hobbs LA, Kaeberle ML, Roth JA (2014) Generation by self re-fusion of bovine(3) x murine(2) heterohybridomas secreting virus-neutralizing bovine monoclonal antibodies to bovine herpesvirus 1 glycoproteins $\mathrm{gB}, \mathrm{gC}$, and gD. Vet Immunol Immunopathol 159(1-2):58-73. https://doi.org/ 10.1016/j.vetimm.2014.02.004

Levings RL, Collins JK, Patterson PA, Roth JA (2015) Virus, strain, and epitope specificities of neutralizing bovine monoclonal antibodies to bovine herpesvirus 1 glycoproteins $\mathrm{gB}, \mathrm{gC}$, and $\mathrm{gD}$, with sequence and molecular model analysis. Vet Immunol Immunopathol 164(34):179-193. https://doi.org/10.1016/j.vetimm.2015.02.009

Li Y, Liang X, van Drunen Littel-van den Hurk S, Attah-Poku S, Babiuk LA (1996) Glycoprotein Bb, the N-terminal subunit of bovine herpesvirus $1 \mathrm{gB}$, can bind to heparan sulfate on the surfaces of MadinDarby bovine kidney cells. J Virol 70(3):2032-2037

Liu ZF, Brum MC, Doster A, Jones C, Chowdhury SI (2008) A bovine herpesvirus type 1 mutant virus specifying a carboxyl-terminal truncation of glycoprotein $\mathrm{E}$ is defective in anterograde neuronal transport in rabbits and calves. J Virol 82(15):7432-7442. https://doi.org/ 10.1128/JVI.00379-08

Mackenzie-Dyck S, Latimer L, Atanley E, Kovacs-Nolan J, Attah-Poku S, Babiuk LA, van Drunen Littel-van den Hurk S (2015) Immunogenicity of a bovine herpesvirus 1 glycoprotein D DNA vaccine complexed with bovine neutrophil beta-defensin 3. Clin Vaccine Immunol 22(1):79-90. https://doi.org/10.1128/CVI. 00476-14

Nandi S, Kumar M, Manohar M, Chauhan RS (2009) Bovine herpes virus infections in cattle. Anim Health Res Rev 10(1):85-98. https://doi.org/10.1017/s1466252309990028

Quattrocchi V, Soria I, Langellotti CA, Gnazzo V, Gammella M, Moore DP, Zamorano PI (2017) A DNA vaccine formulated with chemical adjuvant provides partial protection against bovine herpes virus infection in cattle. Front Immunol 8:37. https://doi.org/10.3389/ fimmu.2017.00037

Ran X, Yang Z, Wen X, Bi Y, Ni H (2017) Preparation of a monoclonal antibody against gd protein of bovine herpesvirus I. Monoclon Antib Immunodiagn Immunother 36(6):282-286. https://doi.org/ 10.1089/mab.2017.0045

Rock DL, Reed DE (1982) Persistent infection with bovine herpesvirus type 1: rabbit model. Infect Immun 35(1):371-373

Ruiz-Saenz J, Jaime J, Vera V (2013) An inactivated vaccine from a field strain of bovine herpesvirus-1 (BoHV-1) has high antigenic mass and induces strong efficacy in a rabbit model. Virol Sin 28(1):36-42. https://doi.org/10.1007/s12250-013-3283-z

Sauerbrei A, Wutzler P (2004) Serological detection of type-specific IgG to herpes simplex virus by novel ELISAs based on recombinant and highly purified glycoprotein G. Clin Lab 50(7-8):425-429

Sibhat B, Ayelet G, Skjerve E, Gebremedhin EZ, Asmare K (2018) Bovine herpesvirus-1 in three major milk sheds of Ethiopia: serostatus and association with reproductive disorders in dairy cattle. Prev Vet Med 150:126-132. https://doi.org/10.1016/j.prevetmed. 2017.12.019

Silva SC, Brum MC, Weiblen R, Flores EF, Chowdhury SI (2010) A bovine herpesvirus 5 recombinant defective in the thymidine kinase (TK) gene and a double mutant lacking TK and the glycoprotein E gene are fully attenuated for rabbits. Braz J Med Biol Res 43(2): 150-159

Theisen-Popp P, Pape H, Muller-Peddinghaus R (1992) Interleukin-6 (IL6 ) in adjuvant arthritis of rats and its pharmacological modulation. Int J Immunopharmacol 14(4):565-571

Theurer ME, Larson RL, White BJ (2015) Systematic review and metaanalysis of the effectiveness of commercially available vaccines against bovine herpesvirus, bovine viral diarrhea virus, bovine respiratory syncytial virus, and parainfluenza type 3 virus for mitigation of bovine respiratory disease complex in cattle. J Am Vet Med Assoc 246(1):126-142. https://doi.org/10.2460/javma.246.1.126

Valera AR, Pidone CL, Massone AR, Quiroga MA, Riganti JG, Corva SG, Galosi CM (2008) A simple method of infecting rabbits with Bovine herpesvirus 1 and 5. J Virol Methods 150(1-2):77-79. https://doi.org/10.1016/j.jviromet.2008.03.008

Valera AR, Fuentealba NA, Zanuzzi CN, Corva SG, Pecoraro MR, Barbeito CG, Galosi CM (2013) Systemic infection induced by intranasal inoculation of Bovine herpesvirus 1.1 in pregnant and non-pregnant rabbits. Res Vet Sci 95(2):709-716. https://doi.org/ 10.1016/j.rvsc.2013.03.017 
Wang X, Bi Y, Ran X, Tong X, Ni H, Wen X (2019) Mapping a highly conserved linear neutralizing epitope on $\mathrm{gD}$ glycoprotein of bovine herpesvirus type I using a monoclonal antibody. J Vet Med Sci 81(5):780-786. https://doi.org/10.1292/jvms.19-0041

Wen X, Cao D, Jones RW, Li J, Szu S, Hoshino Y (2012) Construction and characterization of human rotavirus recombinant VP8* subunit parenteral vaccine candidates. Vaccine 30(43):6121-6126. https:// doi.org/10.1016/j.vaccine.2012.07.078

Wen X, Wen K, Cao D, Li G, Jones RW, Li J, Szu S, Hoshino Y, Yuan L (2014) Inclusion of a universal tetanus toxoid CD4(+) T cell epitope P2 significantly enhanced the immunogenicity of recombinant rotavirus DeltaVP8* subunit parenteral vaccines. Vaccine 32(35):44204427. https://doi.org/10.1016/j.vaccine.2014.06.060
Whetstone CA, Miller JM (1989) Two different strains of an alphaherpesvirus can establish latency in the same tissue of the host animal: evidence from bovine herpesvirus 1. Arch Virol 107(1-2): $27-34$

Zhou Y, Zhu Y, Ren J, Yan H, Wang X, Ma L, Shi H, Xue F (2015) Identification of an antigen epitope on the glycoprotein $\mathrm{D}$ of bovine rhinotracheitis virus. Chin J Prev Vet Med 37(11):871-874+898

Zhu X, Letchworth GJ 3rd (1996) Mucosal and systemic immunity to bovine herpesvirus-1 glycoprotein D confer resistance to viral replication and latency in cattle. Vaccine 14(1):61-69

Publisher's note Springer Nature remains neutral with regard to jurisdictional claims in published maps and institutional affiliations. 